\title{
Effect of postruminal glucose or protein supplementation on milk yield and composition in Friesian cows in early lactation and negative energy balance
}

\author{
BY E. R. ØRSKOV, D. A. GRUBB AND R. N. B. KAY \\ Rowett Research Institute, Bucksburn, Aberdeen AB2 $9 S B$
}

(Received 11 November 1976 - Accepted 10 March 1977)

\begin{abstract}
1. Two experiments were carried out with lactating Friesian cows with a potential for high milk production. Within $3 \mathrm{~d}$ after calving they were fitted with a catheter to allow infusions to be given into the abomasum. During each experiment the milk yields and intake of the cows were such that they were calculated to be in negative energy balance.

2. In the first experiment three cows were infused daily with $10 \mathrm{l}$, the infusate being water, a suspension providing $300 \mathrm{~g}$ casein, or a solution providing $300 \mathrm{~g}$ glucose. The cows were offered a diet of barley straw, rolled barley and urea ad lib. during the first $60 \mathrm{~d}$, after which they were fed to a calculated yield of $7 \mathrm{~kg}$ fat-corrected milk (FCM) less than their previous yield to ensure a negative energy balance. Infusion of casein increased yield by up to $3 \mathrm{~kg} \mathrm{FCM}$ in comparison with glucose or water infusion. It also increased the concentration of crude protein in milk by approximately $13 \%$. There was no consistent effect on milk fat concentration.

3. In the second experiment four cows were used in a trial of Latin-Square design. The basal ration was sufficient for a yield of $10 \mathrm{~kg} \mathrm{FCM} / \mathrm{d}$. Four levels of casein and glucose infused into the abomasum daily were $(\mathrm{g}) 0,750 ; 250,500 ; 500,250 ; 750,0$. The yields of $F C M(\mathrm{~kg} / \mathrm{d})$ were $18 \cdot 9,22 \cdot 7,25 \cdot 2$ and $26 \cdot 1$, the concentration of protein $(\mathrm{g} / \mathrm{kg})$ was $25 \cdot 2,28.4,29.6$ and 31.5 and the concentration of milk fat $(\mathrm{g} / \mathrm{kg})$ was $48 \cdot 2,49 \cdot 8,51 \cdot 0$ and 54.8 for the four treatments respectively. In each instance the increases in values obtained with increasing level of casein infusion were significant. Infusion of casein was calculated to increase the extent of net energy deficit from 20.5 to $41.0 \mathrm{MJ} / \mathrm{d}$. The possible protein limitations for cows in negative energy balance were discussed.
\end{abstract}

The ability of high-producing lactating cows to mobilize body energy reserves in early lactation has long been recognized. Quantitative calorimetric evidence of mobilization was provided by Flatt, Moe, Munson \& Cooper (1969) and more recently by Schiemann, Henseler, Jentsch \& Wittenberg (1974). The extent to which lactating cows are able to mobilize body protein on the other hand has been a matter for conjecture, but the ability to mobilize protein is considerably less than that to mobilize body energy reserves such as fat, although Schiemann et al. (1974) found a substantial negative nitrogen balance in some trials. Coppock, Tyrrell, Merrill \& Reid (1968), for instance, calculated that the labile protein reserve could at most support a yield of about $126 \mathrm{~kg}$ milk, while the fat reserves could with some cows provide the energy required for production of $1000 \mathrm{~kg}$ milk.

These observations have implications for the feeding of dairy cows in early lactation. At this time they are normally in negative energy balance and it would appear that most of the energy mobilized from the tissue would have to be balanced by protein absorbed from the digestive tract.

Several workers have investigated the effect of infusion of casein postruminally, but no experiments have studied critically the effect of protein infusion postruminally when the cows were in negative energy balance. In most experiments reported milk yield and milk protein concentration have increased (Broderick, Kowalczyk \& Satler, 1970; Tyrrell, Bolt, Moe \& Swan, 1972; Spires, Clark \& Derrig, 1973; Derrig, Clark \& Davis, 1974; also Spechter (1972) with cows and Ranawana \& Kellaway (1976) with goats). Negative responses have also been reported with yields of less than $20 \mathrm{~kg}$ milk/d (Vik-Mo, Huber, Bergen, Lichtenwalner \& Emery, 1974). 
Table 1. The number of lactations, live weight post-partum, and previous milk yield of the cows

$\begin{array}{ccccc}\text { Cow no. } & \text { Expt no. } & \text { Lactation } & \begin{array}{c}\text { Wt after } \\ \text { calving } \\ (\mathbf{k g})\end{array} & \begin{array}{c}\text { Yield in } \\ \text { previous } \\ \text { lactation } \\ (\mathbf{k g})\end{array} \\ 36 & 1 & 6 & 538 & 6712 \\ 81 & 1 & 6 & 578 & 6982 \\ 229 & 1 & 2 & 428 & 4545 \\ 15 & 2 & 3 & 514 & 5825 \\ 60 & 2 & 4 & 553 & 6202 \\ 86 & 2 & 4 & 617 & 4930 \\ 214 & 2 & 5 & 536 & 4750\end{array}$

In the experiments reported here glucose or casein were infused postruminally in early lactation to see if mobilization of energy in support of lactation was limited by the amount of protein reaching the tissues or possibly by the availability of glucose for the synthesis of lactose in the mammary gland. A brief account of experiment 2 has been published (Ørskov \& Grubb, 1977).

\section{MATERIALS AND METHODS}

Expt 1

Animals. Information on the three cows used is given in Table 1. Within $3 \mathrm{~d}$ after calving the cows were fitted with a tube to allow infusion of fluid into the abomasum, and the treatment commenced approximately $7 \mathrm{~d}$ after calving.

Surgical preparation of the cows. The catheter used was made from transparent vinyl tubing (Portex Ltd, Hythe, Kent), about $1.2 \mathrm{~m}$ long with $4 \mathrm{~mm}$ internal and $7 \mathrm{~mm}$ external diameter. A circular flange, $20 \mathrm{~mm}$ in diameter, made from $1.5 \mathrm{~mm}$ polyethylene sheeting was fused to the catheter $5 \mathrm{~mm}$ from its end. The cows were denied food and water overnight before the operation. They were catheterized under general anaesthesia induced by intravenous injection of Thiopentone sodium BP (Pentothal; Abbott Laboratories Ltd, Kent) and maintained with Halothane BP (Fluothane; ICI Ltd, Cheshire).

A $160 \mathrm{~mm}$ vertical incision was made in the lower right flank and continued through the abdominal wall. The catheter with its flange was inserted into the lumen of the pyloric antrum about $70 \mathrm{~mm}$ before the pyloric sphincter and held in place by 'purse-string' sutures in the mucosa and serosa. A second polyethylene flange was threaded onto the catheter and the wall of the antrum was drawn over it and secured by another suture. The free end of the catheter was then threaded onto a long, sharp probe which was exteriorized close to the last rib, leaving $100-150 \mathrm{~mm}$ of tubing loose within the abdominal cavity. The probe was then passed subcutaneously parallel to the last rib to exteriorize the catheter between the transverse processes of the lumber vertebrae. About $100 \mathrm{~mm}$ of the catheter was held firmly to the skin by plaster and the end was connected to the infusion tube. Tincture of iodine was applied liberally to the point of exteriorization, but despite this, small abscesses developed within the lower part of the catheter tract of most cows, and these required drainage in two animals.

Design and treatments. The sequences of treatments are given in Table 2. Each treatment period lasted $12 \mathrm{~d}$ after which the infusate was changed. During treatment periods nos 1-5 (Expt 1 a) the cows were fed ad lib. on a mixed diet containing $(\mathrm{g} / \mathrm{kg})$ : ground barley straw 340 , rolled barley 570 , urea 14 , molasses 50 , minerals and vitamins 26 . This diet contained $131 \mathrm{~g}$ crude protein $(\mathrm{N} \times 6 \cdot 25) / \mathrm{kg}$ dry matter (DM). During treatment periods nos 6-8 
(Expt $1 \mathrm{~b}$ ) the cows were fed on the basal diet in amounts sufficient to support a calculated yield of fat-corrected milk (FCM) (Gaines \& Overman, 1938) $7 \mathrm{~kg}$ less than the yields observed in treatment period 5. The requirement of metabolizable energy (ME) for maintenance was taken from Moe, Tyrrell \& Flatt (1970) as $510 \mathrm{~kJ}(122 \cdot 1 \mathrm{kcal}) \mathrm{ME} / \mathrm{kg}^{0.75}$ per d, and the cost of milk synthesis as $1.55 \mathrm{~kJ} \mathrm{ME} / \mathrm{kJ}$ secreted in milk. The basal diet was calculated to supply $11.25 \mathrm{MJ} \mathrm{ME} / \mathrm{kg} \mathrm{DM}$. Each day $10 \mathrm{l}$ fluid was infused into the abomasum over a period of approximately $23 \mathrm{~h}$ using a peristaltic pump (Watson-Marlow, Falmouth, Cornwall). The fluid was a solution of sodium chloride $(1.7 \mathrm{~g} / 1)$, a suspension of casein in sodium carbonate $(3.2 \mathrm{~g} / \mathrm{l})$ providing $300 \mathrm{~g}$ casein/d, or glucose dissolved in a solution of sodium chloride $(1.7 \mathrm{~g} / \mathrm{l})$ providing $300 \mathrm{~g}$ glucose/d. Each infusate provided equal amounts of sodium. The $300 \mathrm{~g}$ casein (Lactic Casein; Glaxo Laboratories Ltd, Greenford, Middlesex) contained $(\mathrm{g} / \mathrm{kg}) 133 \mathrm{~N}, 110$ moisture, 9 ash, 16 fat.

Management. The cows were milked twice daily at 08.00 and 16.30 hours. During the periods in which the cows were offered food ad lib., fresh food was available at all times. The amount of uneaten food was recorded once daily. When restricted amounts were given during treatment periods nos $6-8$, the daily allowance was given in two equal feeds at milking times.

Analytical procedures. Milk yield was recorded daily. Fat was analysed by the Gerber method, $\mathrm{N}$ by the automated Kjeldahl method described by Davidson, Mathieson \& Boyne (1970) and total solids by the procedure of the Association of Official Agricultural Chemists (1965). Milk urea was estimated by the method of Marsh, Fingerhut \& Miller (1965). At the end of the experiment a sample of rumen contents was obtained at 11.00 hours by stomach tube. The samples were analysed for proportions of volatile fatty acids by the method of Fell, Kay, Whitelaw \& Boyne (1968).

Digestibility of diet. The digestibility of the basal diet was determined using four mature castrated sheep fed at maintenance energy level for a period of $14 \mathrm{~d}$. During the last $8 \mathrm{~d}$ the faeces were collected. The digestibility of DM was found to be 0.671 ( \pm 0.021$)$.

\section{Expt 2}

Four Friesian cows were used. Their weights, number of lactations and yields in the previous lactation are given in Table 1 . They were fitted with an abomasal catheter within $2 \mathrm{~d}$ of calving by the surgical procedure described in Expt 1 .

Design and treatments. A $4 \times 4$ Latin-Square design was used with periods of $12 \mathrm{~d}$. The experiment started about $5 \mathrm{~d}$ after catheterization. Fluid $(10 \mathrm{l})$ was infused daily as described in Expt 1. The four treatments consisted of different proportions of casein and glucose dissolved in the infusate. The four treatments were $(\mathrm{g} / \mathrm{d}): 750$ glucose; 500 glucose, 250 casein; 250 glucose, 500 casein; 750 casein. $\mathrm{NaCl}$ was again added to the first three treatments so that, including the $\mathrm{Na}_{2} \mathrm{CO}_{3}$ used for suspending the casein, the same amount of $\mathrm{Na}$ was provided in each treatment. On the last day of each treatment period a blood sample was obtained for the determination of free fatty acids by the method of Duncombe (1964).

Feeding and management. The basal feed had the same composition as for Expt 1. It was given in restricted quantities, calculated from the results of Moe et al. (1970), to supply sufficient energy for maintenance and a daily yield of $10 \mathrm{~kg}$ FCM. The daily allowance was given in two equal feeds at 08.00 and 16.30 hours. The cows were milked twice daily just before they were fed.

Analytical procedures. Milk yield was recorded daily. The contents of fat, protein and total solids were determined on alternate days by the methods described previously for Expt 1. 
Table 3. Comparison of the effect on dry matter intake and milk yield $(\mathrm{kg} / \mathrm{d})$ and protein and fat concentration $(\mathrm{g} / \mathrm{kg})$ of infusion of casein $(C)$ water $(W)$ or glucose $(G)$ into the abomasum of lactating cows

(Both the standard error (SE) of means and the SE of differences (SED) are given)

$\begin{array}{lcccc}\text { Measurement } & \text { Treatments } & \text { Means SE } & \text { Comparison } & \text { Difference sED } \\ \text { Dry matter intake } & \text { W } & 10 \cdot 61 \pm 0.47 & \text { C-W } & 0.51 \pm 0.59 \\ & \text { C } & 11 \cdot 12 \pm 0.36 & \text { C-G } & 0.23 \pm 0.59 \\ \text { Milk yield } & \text { G } & 10.89 \pm 0.47 & & \\ & \text { W } & 14.45 \pm 0.50 & \text { C-W } & 2.51 \pm 0.59 \\ & \text { C } & 16.96 \pm 0.30 & \text { C-G } & 2.84 \pm 0.45 \\ \text { Milk fat } & \text { G } & 14.12 \pm 0.34 & & \\ & \text { W } & 49.31 \pm 1.63 & \text { C-W } & 2.02 \pm 1.90 \\ & \text { C } & 47.29 \pm 0.98 & \text { C-G } & 0.00 \pm 1.46 \\ \text { Milk protein } & \text { G } & 47.29 \pm 1.09 & & \\ & \text { W } & 30.74 \pm 0.81 & \text { C-W } & 4.39 \pm 0.95 \\ & \text { C } & 35 \cdot 13 \pm 0.49 & \text { C-G } & 3.82 \pm 0.73 \\ & \text { G } & 31.31 \pm 0.54 & & \end{array}$

\section{RESULTS}

Expt 1

The results expressed as the means for the last $5 \mathrm{~d}$ of each $12 \mathrm{~d}$ treatment period are given in Table 2. The last $5 \mathrm{~d}$ were chosen since the treatment effect on milk yield and composition had stabilized after $7 \mathrm{~d}$. Casein infusion increased the yield of milk and the amount of $\mathrm{N}$ in the milk.

The treatment means and their differences are given in Table 3, together with the SE of means and differences. There appeared to be no consistent or significant effect of treatment on DM intake. With the casein-water comparison both milk yield $(P<0.01)$ and protein concentration $(P<0.001)$ increased. With the casein-glucose comparisons both milk yield $(P<0.001)$ and milk protein concentrations $(P<0.001)$ were significantly increased. There were no significant effects of the treatment on milk fat concentrations. The proportions of volatile fatty acids (VFA: $\mathrm{mmol} / \mathrm{mol}$ ) recorded in the rumen contents were, on average, acetic acid 591, propionic acid 252 and higher-molecular-weight VFA 157 . The non-glucogenic energy ratio of the VFA (NGR; (acetic acid $+2 \times$ butyric acid + valeric acid: propionic acid + valeric acid, where the amounts of VFA were expressed as molar amounts $(\%)$ ) calculated according to Ørskov (1975) was 3.35.

\section{Expt 2}

The results of Expt 2 are shown in Table 4 where the means for the last $5 \mathrm{~d}$ of each infusion period are given. There were no differences in food intake yet milk yield increased linearly $(P<0.05)$ with increasing concentration of casein in the infusate. The curvilinear trend due to no increase in milk yield resulting from the last increase in casein infused (from 500 to $700 \mathrm{~g} / \mathrm{d})$ approached significance $(P<0 \cdot 1)$. The difference between treatments in the amount of milk fat increased linearly $(P<0.01)$ and therefore the treatment effects were slightly greater when the milk yield was calculated as FCM using the equation of Gaines \& Overman (1938). The $\mathrm{N}$ concentration in the milk and the yield of $\mathrm{N}$ both increased with increasing levels of casein infusion. Both the linear $(P<0.001)$ and quadratic $(P<0.05)$ components of this trend were significant. The concentration of milk solids increased linearly with increasing level of casein infusion $(P<0.01)$ and the concentration 


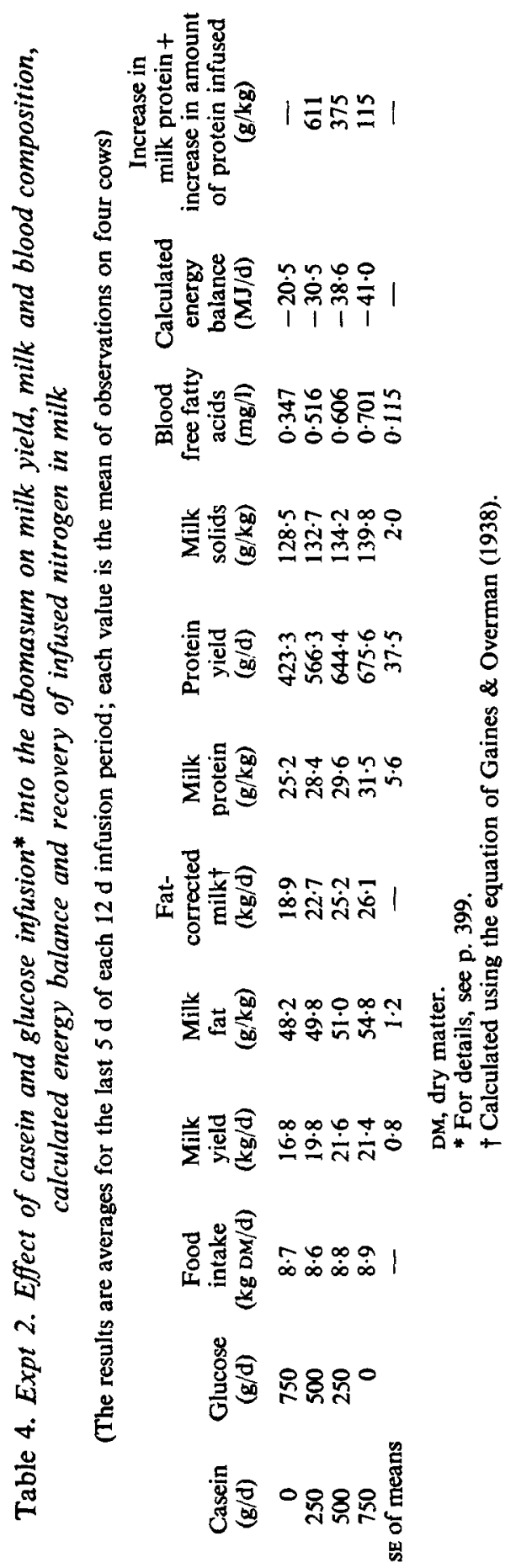


of blood FFA also increased linearly with increasing level of casein infusion $(P<0.05$, for single-tail tests).

From the requirement for maintenance and milk production suggested by Moe et al. (1970), mentioned previously, and the ME content of the feed it was possible to calculate the effect of casein infusion on the extent of net energy deficit by subtracting the potential yield at a particular ME intake from the energy in the milk. It was here assumed that the ME of the infused casein and glucose was equal to their gross energy. Casein infusion doubled the negative energy balance. The apparent recovery of each increment of infused $\mathrm{N}$ was finally calculated. It can be seen that $611 \mathrm{~g}$ protein $/ \mathrm{kg}$ was recovered with the first increment $(0-250 \mathrm{~g}$ casein/d) while from the third increment $(500-750 \mathrm{~g}$ casein/d) only $115 \mathrm{~g}$ protein $/ \mathrm{kg}$ was apparently recovered.

\section{DISCUSSION}

In so far as milk yield responses are concerned the results agree with most published experiments on responses to abomasal infusion of casein, which have been excellently reviewed by Clark (1975).

For almost all experiments reported casein infusion increased the $\mathbf{N}$ concentration of the milk. This increase in milk $N$ here was not due to an increased content of urea. Some, but not all samples were analysed for urea content and there were no treatment differences, the average being $33 \mathrm{mg} / \mathrm{l}$.

The main difference between the experiments reported in the literature and the present work was the imposition of a severe negative energy balance. As the abomasal catheter was inserted soon after calving and the test infusion started within approximately 1 week, the cows could be studied over a period when their high predicted yield might be used to bring them into a massive negative energy balance. In Expt 1 this was clearly the situation for most of treatment periods nos 1-5, and it was imposed by dietary restriction in treatment periods nos 6-8. Expt 2 was designed to obtain additional quantitative information on the effect of increasing the amount of casein infused.

Infusion of casein, by increasing milk yield, clearly caused a further decrease in the energy balance, which according to Table 4 was twice as great with casein as with glucose infusion. If the negative energy balance was due entirely to fat mobilization, then from the factor of 0.82 for conversion of body fat energy to milk energy (Moe et al. 1970) fat mobilization is calculated to have increased from 0.65 to $1.3 \mathrm{~kg} / \mathrm{d}$. This increase in negative energy balance is supported by the increase in the blood concentration of FFA (Annison, 1960). It is of interest here to observe that Sparrow, Hemken, Jacobsen, Button \& Enlow (1973) observed the greatest milk yields and also the greatest weight loss with high yielding dairy cows given a high-protein diet. A similar observation was made with ewes in early lactation (Robinson, Fraser, Gill \& McHattie, 1974).

\section{Mechanism}

It is not possible to explain readily how casein infusion causes an increase in the rate of energy mobilization in the body. In Expt 2 not only did milk yield increase but there was also an increase in milk fat concentration. The results would indicate that in early lactation when the animals are in negative energy balance yield can be severely limited by an inadequacy of amino acids for milk protein synthesis. In this respect it is interesting to observe, as mentioned earlier, that Coppock et al. (1968) calculated that the labile protein in the body of a dairy cow could maximally support a yield of approximately $126 \mathrm{~kg}$ milk; however, many other experiments, and particularly the work of Flatt et al. (1969) show that wellnourished cows have the energy reserve to support milk yields several times this value. 
The lack of response to infusion of glucose suggests that the factor limiting milk yield was not glucose or glucose precursors for synthesis of milk lactose (see Rook, 1976), but protein for synthesis of milk protein since the apparent recovery of $\mathrm{N}$, particularly of the first increment (from 0 to $250 \mathrm{~g}$ casein/d) in Expt 2, was very high $(611 \mathrm{mg}$ protein/g protein infused). It is of course possible that with other basal diets glucose may be limiting yield. In this respect it is of interest that the NGR of the absorbed products of digestion, i.e. non-glucose precursors: glucose precursors, was found to increase to 4.00 before efficiency of utilization for lactation was reduced (Ørskov, 1975). The limited information on the basal diet in the present study showed the NGR to be 3.35. It is thus possible that glucose may be the yield-limiting factor with basal diets giving a much higher NGR.

The effect on fat concentration is difficult to explain since not only did fat concentration follow the increases in yield, but also in Expt 2 fat concentration was significantly increased. More work at a biochemical and cellular level is necessary to elucidate these mechanisms.

\section{Practical implications}

The response of milk yield to protein supplementation postruminally was of a magnitude which is of practical interest. Not only does it seem a possible method for increasing 'peak' lactation but there also may be an effect on the level of production throughout lactation. Broster (1972) discussed the many experiments in which there was a correlation between 'peak'-lactation yield and total lactation yield, showing that a small increase in peak yield can substantially increase the annual yield. The most promising practical development of these results would be to examine the effects of supplementing the diet of dairy cows during the first 5-6 weeks of lactation with a protein-rich concentrate, possibly pure soya-bean meal or fish meal. In order to be effective the supplement used must to a substantial extent escape degradation by rumen micro-organisms, and methods by which ruminal protein degradation could be limited during this period are likely to be of value provided the protein remains digestible in the small intestine (Ørskov, 1977).

The effect of a possible increased weight loss on subsequent reproductive performance needs to be investigated.

The authors wish to thank Mr M. Phillippo, MRCVS, and Mr L. E. Vowles for anaesthetizing the cows, Mr J. Hamilton and the staff of the Duthie Farm, Rowett Research Institute, Bucksburn, for their care of the animals, Mr G. W. Reid for diet preparation, Mr R. I. Smart and his staff for the milk analysis and Mr W. Corrigal, MRCVS, for veterinary supervision.

\section{REFERENCES}

Annison, E. F. (1960). Aust. J. agric. Res. 11, 58.

Association of Official Agricultural Chemists (1965). Official Methods of Analysis, 10th ed, p. 222. Washington, DC: Association of Official Agricultural Chemists.

Broderick, G. A., Kowalczyk, K. T. \& Satler, L. D. (1970). J. Dairy Sci. 53, 1714.

Broster, W. H. (1972). Dairy Sci. Abstr. 34, 265.

Clark, J. H. (1975). J. Dairy Sci. 58, 1178.

Coppock, C. E., Tyrrell, H. F., Merrill, W. G. \& Reid, J. T. (1968). Proc. Cornell Nutr. Conf. p. 86.

Davidson, J., Mathieson, J. \& Boyne, A. W. (1970). Analyst, Lond. 13, 461.

Derrig, R. G., Clark, J. H. \& Davis, C. L. (1974). J. Nutr. 104, 151.

Duncombe, W. G. (1964). Clinica chim. Acta 9, 122.

Fell, B. F., Kay, M., Whitelaw, F. G. \& Boyne, R. (1968). Res, vet. Sci. 9, 458.

Flatt, W. P., Moe, P. W., Munson, A. W. \& Cooper, J. (1969). In Energy Metabolism of Farm Animals [K. L. Baxter, G. Thorbek and J. Kielanowski, editors]. Newcastle-upon-Tyne: Oriel Press.

Gaines, W. L. \& Overman, O. R. (19.38). J. Dairy Sci. 21, 261.

Marsh, W. H., Fingerhut, B. \& Miller, H. (1965). Clin. Chem. 11, 624.

Moe, P. W., Tyrrell, H. F. \& Flatt, W. P. (1970). In Energy Metabolism of Farm Animals, p. 65 [A. Schurch and C. Wenk, editors]. Zurich: Juris Verlag. 
Ørskov, E. R. (1975). Wld Rev. Nutr. Diet. 22, 152.

Ørskov, E. R. (1977). Wld Rev. Nutr. Diet. 26. (In the Press.)

Ørskov, E. R. \& Grubb, D. A. (1977). Proc. Nutr. Soc. 36, 58A.

Ranawana, S. S. E. \& Kellaway, R. C. (1976). Proc. Aust. Soc. Anim. Prod. 11, 489.

Robinson, J. J., Fraser, C., Gill, J. C. \& McHattie, I. (1974). Anim. Prod. 19, 331.

Rook, J. A. F. (1976). In Principles of Cattle Production [H. Swan and W. H. Broster, editors]. London: Butterworths.

Schiemann, R., Henseler, G., Jentsch, W. \& Wittenberg, H. (1974). Archs. Tierernähr. 24, 105.

Sparrow, R. C., Hemken, R. W., Jacobsen, D. R., Button, F. S. \& Enlow, C. M. (1973). J. Dairy Sci. 56, 664.

Spechter, H. H. (1972). Post ruminal casein infusion of urea fed lactating cows. PhD Thesis, University of Guelph, Ontario, Canada.

Spires, H. R., Clark, J. H. \& Derrig, R. G. (1973). J. Dairy Sci. 56, 664.

Tyrrell, H. F., Bolt, D. J., Moe, P. W. \& Swan, H. (1972). J. Anim. Sci. 35, 277.

Vik-Mo, L., Huber, J. T., Bergen, W. G., Lichtenwainer, R. E. \& Emery, R. S. (1974). J. Dairy Sci. 57, 1024. 